This document is re-posted with permission from Riccardo Tartaglia (President of Italian Network for Safety in Health Care)

\title{
PATIENT SAFETY RECOMMENDATIONS FOR COVID-19 EPIDEMIC OUTBREAK
}

\section{Lessons from the Italian Experience}

By Micaela La Regina, Michela Tanzini, Francesco Venneri, Giulio Toccafondi, Vittorio Fineschi, Peter Lachman, Luca Arnoldo, Ilaria Bacci, Alessandra De Palma, Mariarosaria Di Tommaso, Andrea Fagiolini, Marco Feri, Raffaele La Regina, Antonino Morabito, Stefano Parmigiani, Mario Plebani, Elisa Romano, Chiara Seghieri, Pierfrancesco Tricarico, Giorgio Tulli, Riccardo Tartaglia.

\section{International Society For Quality In Health Care}

ISQua

Version - 1.1 (30 March 2020)

Copyright $(\subset$ 2021. This is an open-access article distributed under the terms of the Creative Commons Attribution License (CC BY): Creative Commons - Attribution 4.0 International - CC BY 4.0. The use, distribution or reproduction in other forums is permitted, provided the original author(s) and the copyright owner(s) are credited and that the original publication in this journal is cited, in accordance with accepted academic practice. No use, distribution or reproduction is permitted which does not comply with these terms.

\section{SUMMARY}

INTRODUCTION

1. GENERAL RECOMMENDATIONS FOR THE WORK SYSTEM

2. RECOMMENDATIONS FOR DIAGNOSIS

3. RECOMMENDATIONS FOR HOSPITAL TREATMENT

4. THE ETHICS OF TREATMENT DECISIONS

5. RECOMMENDATIONS RELATED TO SURGERY

6. RECOMMENDATIONS RELATED TO PREGNANT WOMEN

7. RECOMMENDATIONS RELATED TO PEDIATRIC PATIENTS

8. RECOMMENDATIONS RELATED TO HOSPITAL DISCHARGE

9. RECOMMENDATION RELATED TO HOME ISOLATION

10. RECOMMENDATIONS RELATED TO PERSONS IN QUARANTINE (39)

11. RECOMMENDATIONS RELATED TO ONCOLOGIC AND IMMUNOSUPPRESSED PATIENTS

12. MORTUARY/MORGUE OPERATING PROCEDURES

13. PSYCHOLOGICAL SAFETY OF STAFF AND MENTAL WELLBEING OF PATIENTS

14. MEASURES $(51,52,53)$

15. REFERENCES 


\section{INTRODUCTION}

On the basis of reports and questions forwarded to the Clinical Risk Managers of the Italian Network for Health Safety (INSH) from physicians working on the front line, a series of recommendations have been developed referring to documents and papers published by national institutions (ISS) and Italian and international scientific societies and journals. We have arranged the process to describe organising the work system according to the SEIPS Human Factors approach (1).

1. Assess the work system:

a. Team and organisational culture and communication

b. Environment

c. Tasks required and skills to complete tasks

d. Equipment for patient care and to protect staff

e. The people needed to provide care

f. The patients who will receive care

2. Develop reliable pathways of care.

3. Measure the outcomes of care.

ISQua is honoured to publish these recommendations with our partners in Italy. The document is work in progress and will be subject to updates by all professionals on a continuing basis. We appreciate and welcome the contribution of all those involved in COVID-19, both providers of care and patients who have received care: (e-mail info@insafetyhealthcare.it).

\section{GENERAL RECOMMENDATIONS FOR THE WORK SYSTEM}

Building the Team including communication and team culture

1. Emergency taskforce should be promptly activated with a clear chain of command, roles and responsibilities, reliable information sharing tools and proactive approach.

2. Check frequently every day the communications sent by your institutions. Read carefully and respect them. Alternatively, print and make such communication available in the ward and share such information during handovers.
3. Clinical risk management units can support dissemination of documents, guidelines issued by the national institutions for supporting the emergency management, relatively for measures of prevention to be taken. Knowledge about Coronavirus transmission and spreading and clinical characteristics of related disease (COVID-19) are constantly evolving, so that indications for clinical practice change frequently, i.e. case or suspicion definition, criteria for making swabs, etc.

4. The clinical risk management units must keep contact with front line workers and provide support. The reporting of adverse events must occur within the task-force activity and be primarily related to the core activities in time of the pandemic. Secondly, the reporting of Adverse Events should be encouraged in order to maintain the underpinning safety climate in order to prompt corrective and improvement actions. Consider quick reporting tools such as confidential IM or audio-messages (e.g. WhatsApp, WeChat, Telegram, Line etc.)

5. The clinical risk management units should also receive evidence of good practice so this can be disseminated.

\section{Tasks to be undertaken and skills required}

1. Organise brief educational training on the correct use of medical and protective devices targeted to all healthcare workers and develop video tutorials to be available on the healthcare trust website.

2. Hold refresher courses on hand-hygiene, the prevention of VAP (Ventilator Associated Pneumonia) and CLABSI (Central Line Associated Bacterial Infection) bundles and the SEPSIS bundle for early sepsis recognition and management to all healthcare workers (2), but in particular to the staff not in the frontline of the emergency who could be called as replacements.

3. Organise early support of expert doctors/nurses with young or colleagues from other specialties who may be called upon to replace them to properly educate them

4. Do not forget appropriate instructions for environment disinfection (detergents, contact time, frequency) to cleaners (3). 


\section{Equipment needed to protect staff}

1. Contact and droplet precautions can be used in routine patient care of patients with suspected or confirmed COVID-19 (4).

2. Contact and airborne precautions are recommended when performing aerosol generating procedures (AGPS), including intubation and bronchoscopy (4).

3. Prevent biosafety precautions shortage by extended use and limited re-use of full-face shields and disposable facial filtering masks (5), by identifying a priority order to the different wards and by supply of reusable tyvek suits. Store such devices in a locked or secured area and distribute to staff appropriately (5).

The infection spreads so quickly that a depletion of reserve medical supplies is almost unavoidable.

\section{Equipment needed to treat patients}

1. Give suspected or confirmed patients a surgical mask to put on, at their first contact with healthcare services (6).

2. In the dedicated care areas for patients with COVID-19, ensure that:
a. haemo-gas analyzers
b. pulse oximeters
c. oxygen therapy
d. ventilator therapy equipment e.
e. suction pumps.
are available and well-functioning (7).

\section{Environment}

1. Strictly apply, without exceptions, the indications for disinfection of environments and tools (sodium hypochlorite at $0.5 \%$ or $70 \%$ ethyl alcohol solution) (8). It is not yet well known how long the virus resists in the environment, but it is inactivated by solutions based on hypochlorite and alcohol.

2. Prevent germicide deficiency by using galenic preparations.

3. Keep in mind that the creation of dedicated hospitals may divert from the emergencies /emergencies network. Evaluate carefully the fallout of the timing of treatment decisions for time-dependent diseases. Consider the use of underused or quiescent equipped hospitals to meet this need.4. Unless activity is suspended, in the outpatient (public or private) clinics:

a. avoid gatherings in waiting rooms (recommend people wait outside, respecting the distance of at least $1 \mathrm{~m}$ between seats);

b. inform symptomatic subjects with fever and / or cough and / or dyspnea (shortness of breath) not to go to clinics;

c. disseminate hygiene and health standards recommendations in the waiting room.

\section{Patients}

1. Reduce hospital admissions, routine outpatient clinic appointments and routine surgical procedures and regulate hospital visits. Even in absence of strong evidence, it would be a good practice for authorized family members to enter the wards wearing medical masks, due to patients' frailty.

In the full-blown epidemic phase:

a. consider all patients with flu-like symptoms who access hospitals as potentially affected until proven otherwise ( 2 negative swabs at least 48-72h apart);

b. create separate unclean/clean paths, even with the help of external mobile structures (i.e. tents).

2. Contacts of positive patients must follow the instructions provided by those who carry out epidemiological investigation and be clinically evaluated in the locally designated sites, only if symptomatic.

3. Use a screening interview to identify suspected cases before admission to the examination room in case of infection symptoms or to healthcare services for other reasons (i.e. surgery, coronary angioplasty, labour and delivery, etc.)

a. If the criteria of case or suspicion are met, refer the patient for evaluation, according to local procedures.

b. General practitioners will provide their patients with useful information by social networks, email or other tools and keep them updated.

\section{RECOMMENDATIONS FOR DIAGNOSIS}

1. The adequate specimen for Real Time-Polymerase Chain Reaction (RT-PCR) testing is nasopharyngeal 
and oropharyngeal sampling. Prefer lower respiratory tract (LRT; expectorated sputum, endotracheal aspirate, or bronchoalveolar lavage) when readily available (for example, in mechanically ventilated patients). Quality of RT-PCR testing is a crucial issue. Both pre-analytical and analytical variables should be carefully considered, and a validation process should be performed according to ISO 15189 (3 protocols). (9)

2. Many of the most common symptoms of novel coronavirus disease (COVID-19) are like those of common flu or cold. So, it is also suggested knowing which common symptoms of flu or cold are not symptoms of COVID-19. COVID-19 infection seems to rarely cause a runny nose. Rhinorrhea ("runny nose") is not a symptom of COVID-19 and nasal congestion ("stuffy nose) is reported only by $4.8 \%$ of patients (10).

3. The most common COVID-19 symptoms are: fever (88\%), dry-cough (68\%), fatigue (38\%), thick sputum production (34\%), shortness of breath (19\%), arthromyalgia (15\%), sore throat (14\%), headache (13.6\%), chills (11\%), nausea/vomiting (5\%), nasal congestion (4.8\%), diarrhoea (3.7\%). Data from a series of 55,924 laboratory confirmed cases of COVID-19 in China in the period up to February 2020 (11).

4. Beware of patients with gastrointestinal symptoms. Nausea / vomiting and / or diarrhea can be present in about $9 \%$ of cases. These symptoms have so far been one of the most frequent causes of omission or diagnostic delays (11).

5. Unexplained hyposmia, anosmia and dysgeusia could be other symptoms of COVID-19. This issue is currently under investigation (12).

6. Vital signs measurements (do not forget respiratory rate, please) and blood gas analysis in room air, if Sp02 $<94 \%$, at triage or as soon as possible, are essential to correctly assess patients coming to the emergency room $(13,14)$.

7. Do not rely only on $\mathrm{PO} 2<60$ for the diagnosis of respiratory failure, always calculate the $\mathrm{PaO} 2 / \mathrm{FiO} 2$ ratio (P/F ratio), especially in young subjects.

8. Define a "COVID-19 profile" for the rapid order entry of blood tests, including the following tests: blood count,
C-RP, creatinine, electrolytes, blood glucose, albumin, AST ALT, LDH, bilirubin, pneumococcal and legionella urinary agents, PT-INR, troponin and procalcitonin.

9. Chest X-rays have limited sensitivity in early stages of COVID-19 pneumonia. CT scan is more sensitive but raises logistical problems. If ultrasounds competencies are available, use chest US, but disinfect US probes after contact with every COVID-19 suspected patient (15).

10. Monolateral lung infiltrates do not exclude COVID-19. They have been described in $25 \%$ of cases (15).

11. The most common reported laboratory abnormalities in COVID-19 patients are: Lymphopenia (35-75\%), increased C-RP (75-93\%), LDH (27-92\%), ESR (up to $85 \%$ of cases), hypoalbuminemia (50-98\%) and anemia (41-50\%). Data from a systematic revision of literature (16).

12. The following negative prognostic factors have been reported: leukocytosis, neutrophilia, increased procalcitonin, LDH, AST, ALT, total bilirubin, creatinine, troponin, d-dimer, PT and hypoalbuminemia, lymphopenia. Even thrombocytopenia is associated with severe disease $(16,17)$. Severe lymphopenia and lymphocytes count fall during the first 4 days since hospital admissions have been associated with a higher mortality. Increased white blood cell count, neutrophil count and procalcitonin could reflect bacterial superinfection, while increased d-dimer and PT a diffuse intravascular coagulation (DIC), reported in up to $75 \%$ of patients who died (16).

13. History of smoking, respiratory failure, maximum body temperature on admission $37.3^{\circ} \mathrm{C}$, albuminemia $<4$ $\mathrm{mg} / \mathrm{dl}$ would be risk factors for disease progression (severe or critical disease/death). esults from a multivariate analysis on a small sample (OR ranging from 7 to 15) (18).

14. Do not forget other respiratory infections (legionella, pneumococcus, mycoplasma, chlamydia, other respiratory viruses) even if during epidemics, so look for other pathogens and consider antibiotics. During epidemics it is important to avoid availability bias that means diagnose all infections due to epidemic agents. 
WHO recommends investigating other pathogens, as co-infections have been reported (2).

15. Use disease severity stratification for the choice of the treatment setting (home, ordinary, sub-intensive or intensive care unit). WHO distinguishes 6 clinical syndromes associated with COVID-19: uncomplicated disease, mild pneumonia, severe pneumonia, ARDS, sepsis and septic shock. Patients with uncomplicated upper respiratory tract viral infection, may have nonspecific symptoms such as fever, cough, sore throat, nasal congestion, malaise, headache, muscle pain or malaise. These patients do not have any signs of dehydration, sepsis or shortness of breath and can be treated at home (2).

16. Pay attention to elderly people and immunocompromised subjects as they can present vague and/or atypical symptoms (2).

17. Immediately notify the Public Health Officials of COVID-19 positive patients (use infectious disease notification forms) (19).

\section{RECOMMENDATIONS FOR HOSPITAL TREATMENT}

1. Before prescribing antiviral drugs, verify drug-drug and drug-disease interactions, pay particular attention to oral anticoagulants that could be substituted by low molecular weight heparin. Current antiviral therapy schemes include drugs such as lopinavir / ritonavir, chloroquine or hydroxychloroquine, darunavir, cobicistat, tocilizumab, remdesivir $(14,20)$ which present interactions with antibiotics, antiarrhythmics, statins, anti-angina, etc. (Table 1, 2, 3, 4).

2. Angiotensin-converting enzyme (ACE) inhibitors and angiotensin II receptor blockers (ARBs) are safe and should not be discontinued during Coronavirus epidemics (21).

3. There is no proof that ibuprofen can aggravate COVID-19 clinical picture and the European Medicines Agency is monitoring this issue (22).

4. Start oxygen therapy at $5 \mathrm{~L} / \mathrm{min}$ and titrate flow rates to reach SpO2 $\geq 90 \%$ in non-pregnant adults and SpO2 $\geq 92-95 \%$ in pregnant patients (2).
5. High-flow nasal oxygen (HFNO) or non-invasive ventilation (NIV, mainly c-PAP) should only be used in selected patients with hypoxemia, respiratory failure (P/F next to 300 for HFNO and 250-300 for NIV), but with alerts and with preserved ventilator dynamics. Monitor closely for clinical deterioration $(7,23)$.

6. Do not prolong HFNO or NIV for over 2 hours in the case of failure to improve (HFNO: respiratory rate $\geq 24$ / min, NIV: respiratory rate $\geq 28 / \mathrm{min}$ and/or worsening P/F for both) $(7,23)$. High flow nasal cannulas and non-invasive ventilation are not recommended in viral pandemics, based on studies conducted in influenza and MERS (2).

7. Avoid nebulisation therapies for the potential spread of bacteria. Nebulisers generate aerosol particles that can carry bacteria and viruses deep into the lung. The risk of infection transmission may increase with nebulisers as they can generate a high volume of respiratory aerosols that may be propelled over a longer distance than in natural dispersion pattern. Nevertheless, the larger particles may cause cough in both patients' and bystanders' and increase the risk of spreading the disease. Nebulisers in patients with pandemic COVID-19 infection have the potential to transmit potentially viable COVID-19 to susceptible bystander hosts (24).

8. Administer intravenous fluids only if needed and avoid steroids, unless for other indications. Excessive fluid administration could aggravate oxygenation and be dangerous, especially in settings where mechanical ventilation is not readily available. Steroids were not associated with benefits, but rather with damage in the 2003 SARS epidemic and a delay in virus clearance in Middle-Eastern Respiratory Syndrome (MERS) of 2012 (2).

9. Assess thromboembolism and bleeding risk of every patient and provide appropriate thromboprophylaxis. Consider that recovery times and therefore hypo mobility of a subject with COVID-19 are long (at least 15 days in mild forms and up to 6 weeks in severe / critical ones) and diffuse intravascular coagulation (DIC) can complicate the course $(2,15)$. 
10. The Respiratory rate, peripheral oxygen saturation (Sp02) and arterial blood gas analysis results must be monitored closely during hospital stay due to insidious presentation of severe hypoxemia in this disease. Intra-arterial radial catheters insertion is to be considered to reduce arterial punctures, even outside ICU.

11. Also monitor white blood cells, lymphocytes and platelets count, LDH, procalcitonin and d-dimer are considered alarm flags $(13,15,17)$.

12. Be aware of an eventual development of severe form +/- 7 days after symptom onset (13).

13. If a patient reports a SpO $2 \leq 90 \%$ in free air or $\leq 92 \%$ in conventional oxygen therapy and/or presents $\geq 30$ acts/min and/or severe respiratory distress, intensive care therapist consultation must be required (25).

14. Use biosafety precautions when handling oxygen therapy devices (23); cover the patient's face with a surgical mask during HFNO or C-PAP (23); to reduce the risk of aerosolization, possibly use a dual or single circuit non-invasive ventilator with an integrated expiratory valve and a helmet that allows to insert a filter as interface (7).

\section{THE ETHICS OF TREATMENT DECISIONS}

This is a complex issue which will be decided upon in the local setting as per previous ethical frameworks. We recommend that the ethical decision-making process be developed in anticipation of making complex decisions, rather than in reaction to the need to decide.

With regard to management of the patient affected by COVID-19 in intensive care, we offer a number of references which will assist in developing the local ethical guidelines. $(19,25,26,27)$. Other important publications (not included among references): These provide recommendations that can assist in developing local, though may be context specific.

Giacomo Grasselli, Antonio Pesenti, Maurizio Cecconi. Critical Care Utilization for the COVID- 19 Outbreak in Lombardy, Italy Early Experience and Forecast During an Emergency Response. JAMA published online March 2020 https://jamanetwork.com/journals/jama/ fullarticle/2763188
Robert D. Truog, Christine Mitchell and George Q. Daley, Robert D. Truog., Christine Mitchell, George Q. Daley. The Toughest Triage - Allocating Ventilators in a Pandemic This article was published on March 23, 2020, at NEJM.org. https://www.nejm.org/doi/pdf/10.1056/ NEJMp2005689?listPDF=true

Ethical Framework for Health Care Institutions Responding to Novel Coronavirus SARS-CoV- 2 (COVID-19) Guidelines for Institutional Ethics Services Responding to COVID-19 Managing Uncertainty, Safeguarding Communities, Guiding Practice Hastings Institute https:// www.thehastingscenter.org/wpcontent/uploads/HastingsCenterCovidFramework20 20.pdf

\section{RECOMMENDATIONS FOR SURGERY}

These recommendations apply to the medical staff of the operating blocks in case COVID-19. Patients with COVID-19 may need to undergo emergency and/or emergency surgery. The following recommendations should be observed $(29,30,31)$ :

\section{COVID-19 patient positive asymptomatic}

1. Surgical team wearing disposable masks, caps and gloves correctly. Anesthesiologist and assistant nurse: FFP2 masks.

2. Patients must wear a medical mask until I.O.T. (orotracheal intubation).

3. Airway protection of the patient also intubated with TNT drapes compatible with anesthesiologist assistance.

\section{Symptomatic or having few or minor symptoms positive COVID-19 patient}

1. Surgical team wears Personal Protective Equipment (PPE) and FFP2 or FFP3 masks.

2. Anesthesiologist and nurses assigned to direct assistance: FFP2 / FFP3 masks and PPE.

3. Patients must wear a medical mask for the entire time of surgery and / or after the IOT procedure for airway protection with compatible TNT drapes. 


\section{Patient COVID-19 sick and in invasive airway} management.

1. All professionals must wear PPE and FFP2 / FFP3. While staying in the operating room it is recommended to utilise laminar flow according to current legislation and post-intervention sanitisation for at least 1 hour.

\section{Team working and organisation}

Surgical teams in order to stay healthy and maintain continuity of care should divide into teams of senior and junior doctors and work for a 2-week period. After the 2 weeks, teams will come in to release the other. This will allow easier replacement of team members should they fall ill and potential containment of the virus to smaller staff numbers and an ability to maintain some service provision and clinical care.

\section{RECOMMENDATIONS RELATED TO PREGNANT WOMEN}

1. Reduce access of pregnant women to prenatal care, limiting only to high-risk cases (32). There is no evidence of an increased risk of unfavourable maternal or foetal outcomes in the case of COVID-19. However, evidence relating to influenza and SARS-COV1 must induce to consider the pregnant woman as a high-risk patient.

2. Infants born to mothers with confirmed COVID-19 should be considered as suspects. As such, these infants should be isolated from others (33).

3. Separation (i.e. in an individual room) of the infant from the mother with COVID-19 confirmed or suspected, until the precautions based on the transmission risk of the mother are suspended. The decision should be discussed carefully between the caring team and the mother, evaluating risk and benefits of this choice, including the protective potential of colostrum, breast milk and feeding time. $(32,33)$.

4. The discharge of mothers after childbirth must follow the recommendations for discharge of COVID-19 or suspected patients (32).

5. In the case of a woman with suspected SARS-CoV-2 infection or with COVID-19, according to her clinical conditions and desire, breastfeeding should be started and / or maintained directly on the breast or with expressed breast milk (33). If mother and child must be temporarily separated because of mother clinical conditions, one should help the mother to maintain milk production through manual or mechanical/ electric expressing (33). In a limited series reported to date, the presence of the virus in the breast milk of infected women has not been reported, but antiSARS-cov2 antibodies have been found (31). So breast milk would be protective.

6. A mother with confirmed COVID-19 or ongoing swab samples because symptomatic should take all possible precautions to avoid spreading the virus to the baby, including washing hands before touching the baby and wearing a face mask, if possible. during breastfeeding. If using a manual or electric breast pump, the mother must wash her hands before touching the breast pump or parts of the bottle. If possible, have another person administer the milk to the baby (33). It is not yet known whether COVID-19 can be transmitted through breast milk. At present, the main concern is not whether the virus can be transmitted through breast milk, but rather whether an infected mother can transmit the virus through respiratory droplets during breastfeeding (32).

7. For assisting the delivery of women with confirmed or suspected COVID-19, staff must use the safety precautions provided for non-pregnant patients (33).

8. Pregnant women with suspected or confirmed SARSCOV2 infection should be treated with supportive therapies, however taking into account the physiological characteristics of pregnancy (2).

9. The use of experimental therapeutic agents outside of a research study should be guided by an individual risk-benefit analysis based on the potential benefit to the mother and the safety of the foetus, with the consultation of an obstetrician specialist and an ethics committee (2).

10. The decision to proceed to a pre-term birth is based on many factors: gestational age, maternal conditions and foetal stability and requires a collegial evaluation by obstetric, neonatal and intensive care specialists (depending on the mother's condition) (2). 
11. Positivity in itself to Coronavirus is not an indication for a caesarean section which in these patients should only be performed based on other obstetric or medical indications (33).

12. In COVID-19 pregnant women, it is useful to be very cautious in inducing maturity of the lung by means of corticosteroids, since these drugs seem to worsen the course of the infection. If possible, evaluate each case with a neonatologist.

\section{RECOMMENDATIONS RELATED TO PEDIATRIC PATIENTS}

Keep in mind that:

1. To date there is a paucity of information regarding COVID-19 in children.

2. Children and infants are affected and with milder forms (X-ray more often negative; CT more sensitive) (34, 35).

3. A small series of children with COVID-19 has shown a greater prevalence of peripheral halo (halo-sign) lung consolidations on CT (35).

4. The criteria for the definition of Acute Respiratory Distress Syndrome (ARDS) and septic shock, the guidelines for the management of sepsis and septic shock and the use of non- invasive ventilation in children are different from those of adults (2).

5. Children desaturate more easily during intubation; therefore, it is important to pre- oxygenate with $100 \%$ 02 with a mask with a reservoir before intubating (2).

6. A rectal swab may be useful in children to determine the timing of the termination of quarantine. Some authors have used the cycle threshold values of the serial rectal and nasopharyngeal swab tests to indicate viral load. Interestingly, the measurements have indicated that viral shedding from the gastrointestinal system could be greater and last longer than the respiratory tract $(36,37)$.

\section{RECOMMENDATIONS RELATED TO HOSPITAL DISCHARGE}

1. The patient with fever without respiratory failure (normal EGA and walking test) and normal chest x-ray, $<70$ years and without risk factors (lung disease, diabetes mellitus and/ or heart disease) can be discharged from the emergency room $(14,20)$ with indication of home isolation, waiting to run the swab sampling or its result.

The discharge physician:

- obtains a telephone number to contact the patient for swab sampling and / or to communicate the result;

- provides information on how to access the pad (where and when).

If the swab test does not take place in the emergency department, but is performed elsewhere to another area or hospital, it is strictly suggested to use systems to avoid the loss of information. The facility / service running the buffer

- must report the result as soon as it is available to the patient and, if positive, to the Public Health Department for establishing active surveillance.

2. At the end of the hospitalisation, write clearly on the discharge letter:

- CLINICALLY CURED patient (patient with clinical symptoms resolution, but still positive for swab) (38)

or

- CURED patient (patient who, in addition to resolving the symptoms, is negative in two consecutive swabs, carried out at least 24 hours apart) (38).

or

- CLINICALLY CURED PATIENT: write clearly on the discharge letter the indication to be observed at the home quarantine until the swab is negative on two determinations after 24 hours and the execution methods of the control buffer.

Although there is no clear supported evidence, it is considered appropriate to suggest patient retesting no earlier than 7 days and, if negative, confirm the negativity after at least 24 hours (38).

Or DISABLED PATIENT, roommate of patient with positive swab or whose result is not yet known:

- Write clearly the indication of home isolation on the discharge letter (up to 14 days from contact with the infected person) and indication to call the appropriate number (in Italy 112) if symptoms appear; 
- Assure a telephone number to communicate buffer result;

- Communicate swab results as soon as available to the patient and, if positive, to public health trusts, in order to establish active surveillance (38).

\section{RECOMMENDATION RELATED TO HOME ISOLATION}

1. Provide prevention measures and explain them to patients in home isolation also by using designs, charts or pictures.

2. Give also clear indications on alarm symptoms:

a. promote information

b. diffusion of telephone numbers to call in case of occurrence of symptoms

c. Arrangements for support e.g. shopping

3. Provide call centres, online chats, FAQs and video tutorials to consult when there is doubt.

\section{RECOMMENDATIONS RELATED TO PERSONS IN QUARANTINE (39)}

1. Information represents the key success factor; quarantined persons must be constantly informed and updated on the epidemic progress.

2. It is necessary to provide food and other materials and any necessary drugs without making people feel abandoned or alone.

3. The quarantine period should be short, and the duration should not be modified except in extreme circumstances.

4. Most of the side effects derive from the freedom restriction imposition; voluntary quarantine is associated with less stress and fewer long-term complications; therefore, it is necessary to explain clearly the reasons for such suggested behaviours.

5. Public health officials should stress the selfless choice of self-isolation.

Quarantined healthcare workers can be helpful in producing useful documents or other materials while at home for their colleagues. They could contribute by making suggestions and stay in touch with social media.

\section{RECOMMENDATIONS RELATED TO ONCOLOGIC} AND IMMUNOSUPPRESSED PATIENTS

1. Do not indiscriminately discontinue antineoplastic or immunosuppressive therapies. (40-42).

2 . In cancer patients, consider the possibility of postponing the treatment cycle on a case-by-case basis (40).

3. Immunosuppressant withdrawal is indicated if symptoms suggestive of infection appear (41); in this case it is good practice to inform the physician responsible for the treatment promptly.

4. Steroids can be continued, but with caution (41).

5. New immunosuppressant prescriptions or dose increases are not recommended during an epidemic (42).

6. Consider the switch from parenteral drugs to others that can be administered at home (e.g. subcutaneously) to reduce access to outpatient clinics (41).

7. Ensure non-deferred outpatient visits and postpone visits for long-term follow-up, after remote evaluation (telephone, email, etc.) $(40,41)$.

8. Do not allow visitors in therapy rooms and allow the presence of a maximum of one visitor per patient in hospital stays (40).

Please refer also to General Recommendations (section 1) for other indications relating to outpatient clinics.

\section{MORTUARY/MORGUE OPERATING PROCEDURES}

Management of the deceased body with suspect, probable or confirmed COVID-19 respiratory infection. The proposed procedure is aimed at the safe management of the phases of acceptance, handling, custody, and discharge of the body with suspected, probable or confirmed diagnosis of COVID-19 (43). The objective has been pursued by drawing up the following recommendations:

1. The acceptance and handling of the body must be done by personnel equipped wearing the recommended PPE;

2. The body must be positioned on a sanitised metal stretcher for custody and subsequent investigations.

3. At the end of the investigations, the body must be placed in the coffin with the clothes and wrapped in a sheet soaked in disinfectant solution. 
4. If the corpse is required to remain in the mortuary is necessary, pending or at the conclusion of the investigations, the same must take place inside a special closed body bag and dedicated refrigerated room.

5. At the end of the handling and transport operations, all the equipment used must be subjected to sanitisation.

Recommendations for autopsy investigation in cases of suspect, probable or confirmed COVID-19. For the safe and effective performance of HG3 (Hazard Group 3) autopsy investigations, is required:

- generic risk assessment and adoption of universal standard precautions;

- knowledge of possible pathological findings that can be highlighted;

- the definition of SOP (Standard Operating Procedures) for the management of autopsies with high biological risk.

1. The use of universal precautions effectively protects against most risks related to SARS- CoV-2 infection. Professionals have a duty to carry out risk assessment for each case in order to prevent actions that could put operators at risk (44).

2. At the end of the autopsy investigations, the body must be positioned in a body bag and transported in a refrigerated room.

3. Disinfect the outside of the body bag with a hospital disinfectant applied according to the manufacturer's recommendations. It is also recommended in this phase the use of suitable PPE by each operator involved in the movement and exit phases of the body.

\section{Disinfection of autopsy rooms}

In addition, following an autopsy on a subject with suspect or confirmed COVID-19, the following recommendations for disinfection of autopsy rooms should be applied (45):

1. keep ventilation systems active during cleaning;

2. wear disposable gloves when cleaning and handling cleaning or disinfectant solutions;

3. dispose of gloves after cleaning; do not wash or reuse the gloves in any case;
4. use eye protection, such as a visor or goggles, if splashing is expected;

5. if necessary, use respiratory protection based on the type of detergent or disinfectant;

6. wear a long-sleeved waterproof device to protect skin and clothing;

7. use disinfectants with indications of efficacy against human coronaviruses;

8. clean the surfaces and apply the disinfectant ensuring an adequate contact time for effective disinfection;

9. comply with the safety precautions and warnings indicated on the product label (for example, allow adequate ventilation in restricted areas and ensure correct disposal of the unused product or used containers);

10. avoid product application methods that cause the production of splashes or aerosols.

Regarding environmental disinfection, the available evidence has shown that coronaviruses are effectively inactivated by adequate sanitisation procedures that include the use of common hospital disinfectants, such as sodium hypochlorite ( $0.1 \%-0.5 \%)$, ethanol (62-71\%) or hydrogen peroxide $(0.5 \%)$. There is currently no evidence to support a greater environmental survival or a lower sensitivity of SARS-CoV-2 to the aforementioned disinfectants.

1. Hard and non-porous surfaces can be cleaned and disinfected as previously described.

2. Handle with gloves and disinfect properly after use, equipment such as cameras, telephones and keyboards, as well as all objects that remain in the autopsy room.

3. Cleaning activities must be supervised and periodically checked to ensure that correct procedures are followed. Sanitation personnel must be properly trained and equipped with suitable PPE.

4. After cleaning and removing the PPE, wash the hands immediately. Avoid touching the face with gloved or unwashed hands.

5. Environmental disinfection must include cleaning with water and detergent soap on all vertical and horizontal surfaces, followed by disinfection with hospital disinfectants effective against SARS-CoV-2. 
6. For environmental decontamination, it is necessary to use dedicated or disposable equipment. Reusable equipment must be decontaminated after use with a chlorine-based disinfectant. The use of special trolleys is strongly recommended, different from those used for cleaning common areas.

7. The instruments used for autopsies should be autoclaved or treated through chemical sterilisers.

\section{PSYCHOLOGICAL SAFETY OF STAFF AND MENTAL WELLBEING OF PATIENTS}

Psychological safety of staff $(46,47,48,49)$

1. Create a healthy work, ethos and environment during crises and also to have systems in place to deal with subsequent distress and disorder.

2. Organisations which have the foresight to prepare their staff to deal with trauma might consider using interventions such as PFA (Psychological First Aid is a humane, supportive response to a fellow human being who is suffering and who may need support).

3. Consider that factors negatively affecting the psychological well-being of staff are:

- concerns over the contracting the illness

- concerns for safety of their family

- witnessing the death of colleagues

- isolation from family and colleagues

- sense of being underappreciated

- extended length of epidemic

4. Reduce mental health stigma. The best ways of reducing stigma were believed to be raising awareness of mental health issues and telling people that it's quite normal to feel that way and have those feelings;

5. Educate healthcare workers who are exposed to trauma about the effects of cumulative stress. The training should be delivered either online 'because they can do it at their own convenience' or via educational leaflets 'rather than finding the time to spend on a day course'. The education about psychological trauma may lead to better understanding, better recognition of symptoms in oneself and in others, less judgement, and therefore reduced stigma, and that positive relationships with others in the workplace can have a positive impact on psychology.

6. Maintain teamwork and effective leadership while at the same time providing individuals the opportunity to provide input into the decisions that affect their lives. Staff often experience severe emotional stress during viral outbreaks. It is often the nursing staff who feels the greatest level of stress due to their constant contact with sick patients, who may not be improving despite the nursing staff's best efforts. Physicians usually cope somewhat better with this situation because they are in a position to make treatment decisions and are less directly involved in implementing patient care.

7. Be receptive to suggestions from nursing staff and support personnel. Input is empowerment and provides a sense that these critical staff retain some control over their situation. If suggestions are not acted on, clear explanations as to why they were not should be provided and alternatives should be explored.

8. Administration needs to be supportive of staff and not be seen as pedantic and overly controlling.

In cases where staff and support personnel did not feel appreciated or listened to, there was a high degree of dissatisfaction and an increased occurrence of absenteeism and staff strikes, which further reduced personnel in an already-strained system.

9. Take care of yourself and your loved ones. Healthcare providers are not invulnerable to experiencing their own emotional distress during outbreaks, and this distress can be compounded by caring for sick and distressed patients.

10. Make sure your basic needs are met, including: eating, drinking, and sleeping; take a break when you need one; check in with loved ones; practice the strategies to reduce distress listed above; and monitor yourself for stress reactions too.

11. Make efforts to ensure that your office and/or organisation has a viable plan to monitor the course of the outbreak and take rapid and appropriate action if needed. 


\section{Mental well-being of Patients (50)}

1. Medical and mental health clinicians are likely to encounter patients who are experiencing various levels of emotional distress about the outbreak and its impact on them, their families, and their communities. We must consider that COVID-19 patients have long hospital stays and in the early stages they will experience the anguish of having an aggravation of the disease with the possibility of being intubated. Furthermore, the limited staff available will not be able to guarantee them continuous assistance and their relatives as well.

2. Providers should acknowledge uncertainty about emerging diseases and help patients understand that there is often an emotional component to potential health concerns.

3. Providers should be cognisant that the symptoms might extend beyond classical mental health symptoms to include relational struggles, somatic, academic, or vocational issues.

4. Every person, including mental health providers, can either react in fear, anger, or despair and regress, or can choose resilience and play as an active part of the solution.

In addition, providers should consider the following recommendations for promoting patients' mental wellbeing during emerging infectious disease outbreaks:

Be informed: Obtain the latest information about the outbreak from reliable public health resources in order to provide accurate information to your patients.

Educate: Healthcare providers are on the front lines of medical intervention and in a position to influence patient behaviours for protecting individual, family, and public health. Psycho-education is of utmost importance in the aftermath of disasters. Patient education plays a critical role in both containing the disease and mitigating emotional distress during outbreaks. Depending on the nature of the outbreak, this can range from education about basic hygiene such as hand-washing and cough etiquette to more complex medical recommendations for prevention, diagnosis, and treatment.

5. Let patients know what you, your office, or your organisation is doing to reduce the risk of exposure.
6. Correct misinformation. In this age of social media, misinformation can spread quickly and easily, causing unnecessary alarm. If patients present you with inaccurate information related to the outbreak, correct their misconceptions and direct them to vetted public health resources.

7. Limit media exposure. The excess media exposure to coverage of stressful events can result in negative mental health outcomes. Use trusted media outlets to gather the information you need, then turn them off- and advise your patients to do the same.

8. Anticipate and counsel about stress reactions. Emotional distress is a common mental condition in the context of uncertain and potentially life- threatening situations, such as COVID-19 epidemic. A good first step for mitigating your patients' stress is to acknowledge that it exists and help normalise it ("I see that you're stressed, and that's understandable. Many people are feeling this way right now.").

9. Teach patients to recognise the signs of distress, including worry, fear, insomnia, difficulty concentrating, interpersonal problems, avoiding certain situations at work or in daily living, unexplained physical symptoms, and increased use of alcohol or tobacco. This will help them become more aware of the state of their mental health and head off distress before it becomes harder to manage.

10. Discuss strategies to reduce distress, which can include:

- Being prepared (developing a personal/ family preparedness plan for the outbreak).

- Taking everyday preventive measures (e.g., frequent handwashing).

- Maintaining a healthy diet and exercise regimen.

- Talking to loved ones about worries and concerns.

- Engaging in hobbies and activities you enjoy to improve your mood.

- If a patient is experiencing severe emotional distress or has a diagnosable mental illness, refer for specialized mental health care. 


\section{MEASURES $(51,52,53)$}

It is important that we measure the impact of our actions. We include some measures that may be of use.

\section{Outcome measures}

Outcome measures should be collected in order to support the monitoring of effective provider (hospital) epidemic/pandemic response including the capacity to adequately treat patients with other common severe conditions like heart attacks, strokes, trauma, COPD in order to assure that the health of the public is protected to the fullest extent possible:

1. Hospitalisation rate for COVID-19 (indirect outcome measure of the territory).

2. In-hospital Mortality rate of patients hospitalized for COVID-19.

3. Average Length of Stay of COVID-19 patients.

4. Percentage of COVID-19 patients admitted to ICU.

5. In-hospital mortality rate of NO-COVID-19 patients hospitalised for AMI.

6. In-hospital mortality rate of NO-COVID-19 patients hospitalized for Stroke.

7. In-hospital mortality rate of NO-COVID-19 patients hospitalized for COPD.

8. Percentage of NO-COVID-19 hospitalized patients that acquired COVID during the hospitalisation.

9. COVID-19 infection rate among staff / Number of tests performed to hospital staff (as process measure)

10. Survival rates

Where possible indicators 1-7 should be stratified by age groups. Additionally, the proposed outcome measures should be used and interpreted with great caution if used to benchmarking care quality between providers. In this case, consistent data definitions should be adopted and measures from 1 to 7 should be adjusted for potential confounding factors (i.e. patient case mix) in order to draw meaningful and correct comparisons among providers of Mortality rate.

\section{Length of stay measures}

1. Length of Stay

2. Average length of stay in ICU of infected
3. Average length of stay in hospital

\section{Process Measures (some examples)}

1. Percentage of infected individuals admitted to ICU

2. Percentage of people with comorbidities

3. Percentage of staff with and without correct equipment

4. Number of patients not treated in appropriate level of care

5. Percentage staff trained to use equipment

\section{Balancing measures}

1. Staff infection rate

2. Staff mortality rate

3. Staff well being

4. Illness and sickness rates

5. Mental illness

\section{Patient profiles to consider}

- Age

- Gender

- Ethnicity

- Comorbidity

- Region

- Contacts

\section{REFERENCES}

1. Holden RJ, Carayon P, Gurses AP, et al. SEIPS 2.0: a human factors framework for studying and improving the work of healthcare professionals and patients. Ergonomics. 2013;56(11):1669-1686. doi:10.1080/ 00140139.2013 .838643

2. WHO Clinical management of severe acute respiratory infection when novel coronavirus (nCoV) infection is suspected - Interim guidance. Available online at: https://www.who.int/publications-detail/clinicalmanagement-of-severe-acute- respiratory-infectionwhen-novel-coronavirus-(ncov)-infection-is-suspected

3. Australian government Department of Health, Environmental cleaning and disinfection principles for COVID-19 Available online at: https://www.health.gov.au/sites/ default/files/documents/2020/03/environmentalcleaning-and-disinfection-principles-for-COVID-19.pdf 
4. Chi Chiu Leung, Tai Hing Lam, Kar Keung Cheng. Mass Masking in the COVID 19 epidemic: people need guidance. The Lancet March 03, 2020 https://doi. org/10.1016/S0140-6736(20)30520-1 Available online at: https://www.thelancet.com/journals/lancet/ article/PIIS0140-6736(20)30520-1/fulltext

5. Nebraska Medicine COVID-19 PPE Guidance, Extended Use and Limited Reuse of Disposable Facemasks, Respirators and Protective Eyewear Available online at: https://snlg.iss.it/wp-content/uploads/2020/03/ COVID-Extended-Use-Reuse-of-PPE- and-N95-ext.pdf

6. Australian government Department of Health, Interim advice on non-inpatient care of persons with suspected or confirmed Coronavirus disease (COVID-19), including use of personal protective equipment (PPE) Available online at: https://www.health.gov.au/resources/ publications/interim-recommendations-for- the-useof-personal-protective-equipment-ppe-during-hospitalcare-of-people-with- coronavirus-disease-2019-COVID-19

7. Ferrari R, Groff P, Cosentini R, Indicazioni all'uso dei presidi per l'ssigenzazione dei pazienti con polmonite da COVID-19. Parte 2: Il ruolo della C-PAP Available online at: https://www.simeu.it/w/articoli/ leggiArticolo/3991/leggi

8. World Health Organization. Water, sanitation, hygiene and waste management for COVID-19, Technical brief 19th March 2020 Available online at: https://www. who.int/publications-detail/water-sanitation-hygieneand-waste- management-for-COVID-19

9. Lippi G, Simundic AM, Plebani M. Potential preanalytical and analytical vulnerabilities in the laboratory diagnosis of coronavirus disease 2019 (COVID-19). Clin Chem Lab Med. 2020 Mar 16. pii:/j/cclm.ahead-of-print/ cclm-2020-0285/cclm-2020-0285.xml. doi:10.1515/ cclm-2020-0285. [Epub ahead of print] Available online at: https://www.degruyter.com/view/j/cclm. ahead-of-print/cclm-2020-0285/cclm-2020- 0285.xml

10. Roser M, Richie H, Oritiz-Ospina E, Coronavirus Disease (COVID-19) - Statistics and Research Available online at: https://ourworldindata.org/coronavirus

11.World Health Organization (2020). Report of the WHO-China Joint Mission on Coronavirus Disease 2019 (COVID-19). Available online at: https://www.who.int/ docs/default-source/coronaviruse/who-china-jointmission-on- COVID-19-final-report.pdf

12.Worcester S., Reports increasingly suggest anosmia/ hyposmia can signal early COVID- 19 infection, The Hospitalist, published on March 24th 2020. Available online at: https://www.the-hospitalist.org/ hospitalist/article/219556/coronavirus- updates/ reports-increasingly-suggest-anosmia/hyposmia-can

13."Rapporto Prima Linea COVID-19 assetto organizzativo gestionale dei PS/DEA nell'ambito di focolaio epidemico o pre-epidemico" (SIMEU 07/03 /2020) Available online at: https://www.simeu.it/w/articoli/ leggiArticolo/3964/leggi

14. Linee guida Cinesi sulla gestione di COVID-19 (versione 7), pubblicate dalla Salute Nazionale della R.P.C.e dalla Amministrazione Nazionale della Medicina Tradizionale della R.P.C. in data 3/3/2020 Available online at: https://www.nursetimes.org/wp- content/ uploads/2020/03/Linee-guida-cinesi-sulla-gestioneCOVID-19-versione-7- ita.pdf.pdf

15. Kooraki S et al. Coronavirus (COVID-19) Outbreak: What the Department of Radiology Should Know, J Am Coll Radiol 2020 Available online at: https://www.jacr. org/article/S1546-1440(20)30150-2/pdf

16.Lippi G, Plebani M, Laboratory abnormalities in patients with COVID-2019 infection. ClinChem Lab Med 2020 Published Online: 2020-03-03 Available online at: https://www.degruyter.com/doi/10.1515/ cclm-2020-0198

17.Lippi G, Plebani M, Michael Henry B. Thrombocytopenia is associated with severe coronavirus disease 2019 (COVID-19) infections: A meta-analysis. Clin Chim Acta. 2020 Mar 13. pii: S0009-8981(20)30124-8. doi: 10.1016/j.cca.2020.03.022. [Epub ahead of print] Available online at: https://www.sciencedirect.com/ science/article/pii/S0009898120301248?via\%3Dihu b

18. Wei Liu et al. Analysis of factors associated with disease outcomes in hospitalized patients with 2019 novel coronavirus disease Chinese Medical Journal 2020 DOI: $10.1097 / C M 9.0000000000000775$ Available online at: https://journals.lww.com/cmj/Abstract/ publishahead/Analysis_of_factors_associate d_with_disease.99363.aspx 
19. Ministero della Salute, All.3 Polmonite da nuovo Coronavirus in Cina. Available online http://www. trovanorme.salute.gov.it/norme/renderNormsanPdf? anno $=2020 \&$ codLe $g=72796 \&$ parte $=1 \% 20 \&$ serie $=$ null

20. Regione Emilia Romagna, Protocollo terapeutico per la terapia antivirale dei pazienti con infezione da COVID-19, aggiornato al 9 marzo 2020

21. Position Statement of the ESC Council on Hypertension on ACE-Inhibitors and Angiotensin Receptor Blockers, published on 13th march 2020 Available online at: https://www.escardio.org/Councils/Council-onHypertension-(CHT)/News/position- statement-of-theesc-council-on-hypertension-on-ace-inhibitors-and-ang

22. EMA gives advice on the use of non-steroidal antiinflammatories for COVID-19, published on 18th march 2020 Available online at: https://news/ema-givesadvice- use-non-steroidal-anti-inflammatories-COVID-19

23.Groff P, Cosentini R, Ferrari R, Indicazioni all'uso dei presidi per l'ossigenazione dei pazienti con polmonite da COVID-19. Parte 1: Il ruolo delle HFNO Available online at: https://www.simeu.it/w/articoli/ leggiArticolo/3991/leggi

24.Amirav I, RE: Transmission of Corona Virus by Nebulizer- a serious, underappreciated risk! published on 3rd march 2020 Available online at: https://www.cmaj. ca/content/re-transmission-corona-virus-nebulizerserious- underappreciated-risk

25.SIAARTI, Percorso COVID-19, Sezione 1 - Procedura Area critica, pubblicato il 14 marzo 2020 Available online at: http://www.siaarti.it/SiteAssets/News/ COVID- 19\%20-\%20documenti\%20SIAARTI/Percorso $\% 20$ COVID-19\%20-\%20Sezione $\% 201 \% 20 \% 20$ -\%20Procedura\%20Area\%20Critica.pdf

26.SIAARTI, Percorso COVID-19, Sezione 2 - Raccomandazioni per la gestione locale, pubblicato il 14 marzo 2020 Available online at: http://www.siaarti.it/SiteAssets/News/COVID-19\%20-\%20documenti\%20 SIAARTI/Percorso\%20COVID-19\%20-\%20Sezione\%20 2\%20-\%20Raccomandazioni\%20per\%20la\%20gestione $\% 20$ locale.pdf

27.SIAARTI, COVID-19 - Airway management Rev 1.2 Available online at: http://www.siaarti.it/SiteAssets/ News/COVID-19\%20-\%20documenti\%20SIAARTI/
SIAARTI\%20-\%20COVID-19\%20-\%20Airway\%20 Management\%20rev.1.2.pdf

28. SIAARTI, Clinical Ethics Recommendations for the Allocation of Intensive Care Treatments in exceptional, resource-limited circumstances - Version n. 1 Posted on March, 16th - 2020 http://www.siaarti.it/SiteAssets/ News/COVID-19\%20-\%20documenti\%20SIAARTI/ SIAARTI\%20-\%20COVID-19\%20-\%20Clinical\%20 Ethics\%20Reccomendations.pdf

29.Procedura aziendale USL Toscana Centro Firenze. Paziente COVID-19 in emergenza del 3 marzo 2020 PA 03.1B1

30.Cambieri A., Girardi F., et.al., Il Reparto OperatorioProgettazione, organizzazione, controllo- Il Pensiero Scientifico Editore, 2010

31.Finzi GF.,Aparo L.,et.al. -Governo e Gestione dell'Igiene nelle strutture sanitarie - Manuale Pratico - Il Pensiero Scientifico Editore 2008

32. Center for disease control and prevention, Interim Considerations for Infection Prevention and Control of Coronavirus Disease 2019 (COVID-19) in Inpatient Obstetric Healthcare Settings Available online at: https://www.cdc.gov/coronavirus/2019-ncov/hcp/ inpatient-obstetric-healthcare-guidance.html

33.SIAARTI, COVID-19: gravidanza, parto e allattamento Available online at: http://www.siaarti.it/News/ COVID\%2019\%20gravidanza,\%20parto\%20e\%20 allattam ento.aspx

34.W. Liu et al. Detection of COVID-19 in children in early January 2020 in Wuhan, China, Correspondence NEJJM March 122020 DOI: 10.1056/NEJMc2003717 Available online at: https://www.nejm.org/doi/full/10.1056/ NEJMc2003717

35. Wei Xia et al. Clinical and CT features in pediatric patients with COVID-19 infection: different point from adults, Ped Pneumol 5 march 2020 Available online at: https://onlinelibrary.wiley.com/doi/full/10.1002/ ppul.24718

36.Zhu $\mathrm{N}$ et al. A novel coronavirus from patients with pneumonia in China, 2019. N Engl J Med 2020 Jan 24; [e-pub]. Available online at: https://doi.org/10.1056/ NEJMoa2001017 
37. Xu, Y., Li, X., Zhu, B. et al. Characteristics of pediatric SARS-CoV-2 infection and potential evidence for persistent fecal viral shedding.Nat Med (2020). https://www. nature.com/articles/s41591-020-0817-4?proof=trueIn

38. Rapporto ISS COVID-19 n.1/2020, Indicazioni ad interim per l'effettuazione dell'isolamento e dell'assistenza sanitaria domiciliare nell'attuale contesto COVID-19 Available online at: https://www.iss.it/documents/20126/0/Rapporto+ISS+COVID-19+1_2020+IS OLAMENTO+DOMICILIARE.pdf/47e9ffab-61ba-78fbbab7- cc600d660ee7?t=1583831542224

39. Samantha K Brooks, Rebecca K Webster, Louise E Smith, Lisa Woodland, Simon Wessely, Neil Greenberg, Gideon James Rubin. The psychological impact of quarantine and how to reduce it: rapid review of the evidence. Lancet 2020; 395: 912-20 Published Online February 26, 2020 Available online at: https://doi.org/10.1016/ S0140-6736(20)30460-8

40. Rischio infettivo da Coronavirus COVID-19 Indicazioni per l'oncologia Available at: https://www.aiom.it/ wp-content/uploads/2020/03/20200313_COVID19_indicazioni_AIOM-CIPOMO-COMU.pdf

41. R. Mao et al. Implications of COVID-19 for patients with pre-existing digestive diseases, The Lancet Gastroenterology and hepatology, Published on March 11th, 2020 DOI:https://doi.org/10.1016/S2468-1253(20)30076-5

42.EULAR Guidance for patients COVID-19 outbreak Published on March 17th, 2020 Available online at: https:// www.eular.org/eular_guidance_for_patients_COVID19_outbreak.cfm

43. Management of the corpse with suspect, probable or confirmed COVID-19 respiratory infection - Italian interim recommendations for personnel potentially exposed to material from corpses, including body fluids, in morgue structures and during autopsy practice. Vittorio Fineschi on behalf of the Scientific Society of Hospital Legal Medicine of the National Health System (COMLAS) and Anna Sapino on behalf of the Italian Society of Anatomical Pathology and Cytology (SIAPEC), Pathologica, in press.

44. Health and Safety Executive. Managing infection risks when handling the deceased. Guidance for the mortuary, post-mortem room and funeral premises, and during exhumation. Available at: https://www.hse. gov.uk/pUbns/priced/hsg283.pdf

45. The Royal College of Pathologists. Briefing on COVID-19. Autopsy practice relating to possible cases of COVID-19 (2019-nCov, novel coronavirus from China 2019/2020). Available at: https://www.rcpath.org/uploads/assets/d5e28baf-5789-4b0f- acecfe370eee6223/ fe8fa85a-f004-4a0c-81ee4b2b9cd12cbf/Briefing-onCOVID-19- autopsy-Feb-2020.pdf

46.Samantha K. Brooks, Rebecca Dunn, Richard Amlôt, G. James Rubin and Neil Greenberg, Protecting the psychological wellbeing of staff exposed to disaster or emergency at work: a qualitative study BMC Psychology (2019) 7:78 https://doi.org/10.1186/ s40359-019-0360-6

47.Samantha K. Brooks, Rebecca Dunn, Richard Amlôt, G. James Rubin \& Neil Greenberg Social and occupational factors associated with psychological wellbeing among occupational groups affected by disaster: a systematic review. J Ment Health, Early Online (2017): 1-12, DOI: 10.1080/09638237.2017.1294732

48.Solon R. Providing Psychological First Aid Following a Disaster. Occup Health Saf. 2016 May;85(5):40, 42, 44. Available online at: https://ohsonline.com/ Articles/2016/05/01/Providing-Psychological-FirstAid- Following-a-Disaster.asp $\mathrm{x}$

49.WHO, War Trauma Foundation and World Vision International Psychological first aid: Guide for field workers Available online at: https://apps.who.int/iris/ bitstream/handle/10665/44615/9789241548205ita.pdf?ua $=1$

50.Center for the Study of Traumatic Stress Department of Psychiatry. Caring for Patients' Mental Well-Being During Coronavirus and Other Emerging Infectious Diseases: A Guide for Clinicians (2020) Available online at: https://www.cstsonline.org/assets/media/documents/CSTS_FS_Caring_for_Patients_Mental_WellBeing_during_Coronavirus.pdf.pdf

51.European Centre for Disease Prevention and Control. Novel coronavirus disease 2019 (COVID-19) pandemic: increased transmission in the EU/EEA and the UK sixth update - 12 March 2020. Stockholm: ECDC; 2020. Available online at: https://www.ecdc.europa.eu/sites/ 
default/files/documents/RRA-sixth-update- Outbreakof-novel-coronavirus-disease-2019-COVID-19.pdf

52.World Health Organization (WHO). Pandemic Influenza Severity Assessment (PISA): A WHO guide to assess the severity of influenza epidemics and pandemics. Geneva 2017. Available online at: https://apps.who.
int/iris/bitstream/handle/10665/259392/WHOWHE-IHM-GIP- 2017.2-eng.pdf?sequence $=1$

53.Wang D, Hu B, Hu C, et al. Clinical Characteristics of 138 Hospitalized Patients With 2019 Novel CoronavirusInfected Pneumonia in Wuhan, China. JAMA (2020); 323(11): 1061-1069. Available online at: https:// jamanetwork.com/journals/jama/fullarticle/2761044

\section{APPENDIX - MEDICATIONS}

TABLE 1. Chloroquine and hydroxy-chloroquine: main Italian drug interactions

\begin{tabular}{|c|c|}
\hline DRUGS & INTERACTIONS \\
\hline Chloroquine & $\begin{array}{l}\text { Antacids based on aluminum, calcium and magnesium and kaolin can reduce their absorption. } \\
\text { In association with: } \\
\text { - Corticosteroids accentuation of any myopathies or cardiomyopathies } \\
\text { - Phenylbutazone can induce exfoliative dermatitis } \\
\text { - Isoniazid, Amiodarone, Carbamazepine, Phenytoin, Phenothiazide, Ketoconazole and } \\
\text { MAO inhibitors (Mono-Amino-Oxidase Inhibitors) risk of hepatotoxicity } \\
\text { - Mefloquine and bupropion risk of convulsions } \\
\text { - Petronidazole possible dystonic reactions } \\
\text { - Pyrimetamine / sulfadoxineskin reactions } \\
\text { Effects of chloroquine on other drugs: } \\
\text { - Ampicillin reduced absorption (administer at least } 2 \text { hours after chloroquine) } \\
\text { - Class IA and III antiarrhythmics, Tricyclic antidepressants, Antipsychotics increased } \\
\text { - } \text { risk of ventricular arrhythmia } \\
\text { - Cyclopileptic antagonism on anticonvulsant effects } \\
\text { - Digoxin increase in plasma concentration and relative toxicity } \\
\text { - Methotrexate potentiation of the action } \\
\text { - Neostigmine and Pyridostigmine antagonism of the effects } \\
\text { - Vaccines antibody response reduction ONLY with rabies vaccine }\end{array}$ \\
\hline Hydroxy- chloroquine & $\begin{array}{l}\text { In association with: } \\
\text { - Phenylbutazone can induce exfoliative dermatitis } \\
\text { - Isoniazid, Amiodarone, Carbamazepine, Phenytoin, Phenothiazide, Ketoconazole and } \\
\text { MAO inhibitors (Mono-Amino-Oxidase Inhibitors) can cause hepatoxicity } \\
\text { Effects of hydroxychloroquine on other drugs } \\
\text { - Anti-epileptics antagonism on anticonvulsant effects } \\
\text { - Cyclosporine increased plasma concentrations } \\
\text { - Digoxin increased plasma concentration and relative toxicity } \\
\text { Insulin and Antidiabetics potentiation of hypo-glycemic effects }\end{array}$ \\
\hline
\end{tabular}


TABLE 2. LOPINAVIR/RITONAVIR: Main Italian interactions and recommendations

\begin{tabular}{|c|c|c|}
\hline Co-administered Drug & Mechanism of interaction & Clinical Recommendations \\
\hline $\begin{array}{l}\text { RETROVIRAL AGENTS: } \\
\text { Nucleoside reverse transcriptase } \\
\text { inhibitors (NRTIs), Non-nucleoside } \\
\text { reverse transcriptase inhibitors } \\
\text { (NNRTIs), HIV CCR5 } \\
\text { - antagonist, Integrase inhibitor, } \\
\text { Inhibitors of HIV protease }\end{array}$ & & $\begin{array}{l}\text { Specialist advice, dose adjustment is not } \\
\text { required in most cases. Co- administration } \\
\text { with other HIV protease inhibitors (PIs), } \\
\text { according to current guidelines, is not } \\
\text { recommended. }\end{array}$ \\
\hline Antacids & & No contraindications \\
\hline \multicolumn{3}{|l|}{ Alpha antagonists } \\
\hline ALFUZOSIN & Increased concentration (CYP3A inhibition) & Contraindicated (hypotension) \\
\hline \multicolumn{3}{|l|}{ Analgesic Drugs } \\
\hline FENTANYL & Increased concentration (CYP3A inhibition) & Close monitoring (risk of respiratory \\
\hline \multicolumn{3}{|l|}{ Antianginal Drugs } \\
\hline RANOLAZINE & Increased concentration (CYP3A inhibition) & Contraindicated \\
\hline Co-administered Drug & Mechanism of interaction & Clinical Recommendations \\
\hline \multicolumn{3}{|l|}{ Antiarrhythmics } \\
\hline AMIODARONE, DRONEDARONE & Increased concentration (CYP3A inhibition) & Contraindicated (arrhythmia) \\
\hline DIGOXIN & Increased concentration (P-gp inhibition) & Plasma level monitoring \\
\hline $\begin{array}{l}\text { BEPRIDIL, SYSTEMIC LIDOCAINE, } \\
\text { QUINIDINE }\end{array}$ & Increased concentration & Plasma level monitoring \\
\hline \multicolumn{3}{|l|}{ Antibiotics } \\
\hline CLARITHROMYCIN & $\begin{array}{l}\text { Moderate increase of under-curve area } \\
\text { (CYP3A inhibition) }\end{array}$ & $\begin{array}{l}\text { Dose reduction in kidney failure }(\mathrm{CrCL}<30 \\
\mathrm{ml} / \mathrm{min}) ; \text { attention in patients with impaired } \\
\text { liver and kidney function }\end{array}$ \\
\hline Antineoplastics & & Specialist Advice \\
\hline \multicolumn{3}{|l|}{ Anticoagulants } \\
\hline WARFARIN & CYP2C9 induction & INR monitoring \\
\hline RIVAROXABAN & $\begin{array}{l}\text { AUC: } \uparrow 153 \%, \text { Cmax: } \uparrow 55 \% \text { (CYP3A and } \\
\text { P-gp inhibition) }\end{array}$ & Contraindicated (bleeding) \\
\hline VORAPAXAR & Increased concentration (CYP3A inhibition) & Contraindicated \\
\hline \multicolumn{3}{|l|}{ Antiepileptic } \\
\hline PHENYTOIN & $\begin{array}{l}\text { Concentrazioni diminuite (induzione del } \\
\text { CYP2C9 e del CYP2C19) }\end{array}$ & Plasma level monitoring \\
\hline CARBAMAZEPINE, PHENOBARBITAL & $\begin{array}{l}\text { Increased Carbamazepine concentration (CYP3A } \\
\text { inhibition); reduced Lopinavir concentration } \\
\text { (CYP3A induction) }\end{array}$ & Plasma level monitoring \\
\hline
\end{tabular}




\begin{tabular}{|c|c|c|}
\hline Co-administered Drug & Mechanism of interaction & Clinical Recommendations \\
\hline \multicolumn{3}{|l|}{ Antidepressants and anxiolytics } \\
\hline TRAZODONE & AUC: $\uparrow 2,4$ times & Dose reduction \\
\hline \multicolumn{3}{|l|}{ Antifungals } \\
\hline KETOCONAZOLE & Increased concentration (CYP3A inhibition) & Dose reduction \\
\hline Co-administered Drug & Mechanism of interaction & Clinical Recommendations \\
\hline \multicolumn{3}{|l|}{ Anti-gout } \\
\hline COLCHICINE & $\begin{array}{l}\text { AUC: } \uparrow 3 \text {-times; Cmax: } \uparrow 1,8 \text {-times (CYP3A } \\
\text { and/or P-gp inhibition) }\end{array}$ & Contraindicated \\
\hline \multicolumn{3}{|l|}{ Antihistamines } \\
\hline ASTEMIZOLE, TERFENADINE & Increased concentration (CYP3A inhibition) & Contraindicated (severe arrhythmias) \\
\hline \multicolumn{3}{|l|}{ Anti-Infectives } \\
\hline Fusidic Acid & Increased concentration (CYP3A inhibition) & Contraindicated (rhabdomyolysis) \\
\hline Anti-mycobacterial agents & & Specialist Advice \\
\hline \multicolumn{3}{|l|}{ Benzodiazepines } \\
\hline MIDAZOLAM & $\begin{array}{l}\text { Oral administration: AUC: } \uparrow 13 \text {-times } \\
\text { parenteral administration: AUC: } \uparrow 4 \text {-times } \\
\text { (CYP3A inhibition) }\end{array}$ & $\begin{array}{l}\text { Oral administration contraindicated; close } \\
\text { monitoring for parenteral administration }\end{array}$ \\
\hline \multicolumn{3}{|l|}{ Beta 2 agonists } \\
\hline SALMETEROL & Increased concentration (CYP3A inhibition) & $\begin{array}{l}\text { Contraindicated (severe cardiovascular event } \\
\text { and arrhythmias) }\end{array}$ \\
\hline \multicolumn{3}{|l|}{ Calcium Channel Blockers } \\
\hline \multicolumn{3}{|l|}{$\begin{array}{l}\text { FELODIPINE, NIFEDIPINE, } \\
\text { NICARDIPINE }\end{array}$} \\
\hline \multicolumn{3}{|l|}{ Steroids } \\
\hline DEXAMETHASONE & $\begin{array}{l}\text { Reduction of Lopinavir concentrations (CYP3A } \\
\text { induction) }\end{array}$ & Clinical monitoring of anti- viral activity \\
\hline $\begin{array}{l}\text { Phosphodiesterase inhibitors } \\
\text { AVANAFIL, SILDENAFIL }\end{array}$ & Increased concentration (CYP3A inhibition) & Contraindicated \\
\hline \multicolumn{3}{|l|}{ Ergot Alkaloids } \\
\hline $\begin{array}{l}\text { DIHYDROERGOTAMINE AND } \\
\text { OTHERS }\end{array}$ & Increased concentration (CYP3A inhibition) & Contraindicated \\
\hline \multicolumn{3}{|l|}{ Intestinal Prokinetics } \\
\hline CISAPRIDE & Increased concentration (CYP3A inhibition) & Contraindicated \\
\hline Direct anti-HCV agents & $\begin{array}{l}\text { Increased plasma concentration } \\
\text { (combined mechanisms) }\end{array}$ & Contraindicated \\
\hline $\mathrm{HCV}$ protease inhibitors & & Contraindicated \\
\hline
\end{tabular}


PATIENT SAFETY RECOMMENDATIONS FOR COVID-19 EPIDEMIC OUTBREAK: Lessons from the Italian Experience

\begin{tabular}{|c|c|c|}
\hline Co-administered Drug & Mechanism of interaction & Clinical Recommendations \\
\hline \multicolumn{3}{|l|}{ Immuno-suppressers } \\
\hline CICLOSPORINE & Increased concentration (CYP3A inhibition) & Plasma level monitoring \\
\hline Statins & & $\begin{array}{l}\text { Contraindicated; fluvastatin and pravastatin } \\
\text { tolerated }\end{array}$ \\
\hline \multicolumn{3}{|l|}{ Opioids } \\
\hline METHADONE & Decrease in concentration & Plasma level monitoring \\
\hline \multicolumn{3}{|l|}{ Contraceptives } \\
\hline Ethinylestradiol & Decrease in concentration & Use additional contraceptive methods \\
\hline \multicolumn{3}{|c|}{ Hormone Replacement Therapy (HRT) } \\
\hline Levothyroxine & Potential interactions not well documented & $\begin{array}{l}\text { TSH monitoring } \\
\text { during the first month from the beginning } \\
\text { and / or from the end of the treatment }\end{array}$ \\
\hline
\end{tabular}


TABLE 3. DARUNAVIR/COBICISTAT: Main Italian interactions and recommendations

\begin{tabular}{|c|c|c|}
\hline Co-administered Drug & Interaction mechanism & Clinical Recommendations \\
\hline \multicolumn{3}{|l|}{ Anti-retroviral agents (HIV) } \\
\hline $\begin{array}{l}\text { Inhibitors of the strand transfer of ' integrase, } \\
\text { inhibitors nucleoside / nucleotide HIV reverse } \\
\text { transcriptase inhibitors (NRTIs) }\end{array}$ & & $\begin{array}{l}\text { Specialist advice, no dose adjustment } \\
\text { necessary, except for Emtricitabine / } \\
\text { tenofovir alafenamide }\end{array}$ \\
\hline $\begin{array}{l}\text { Non- nucleoside / nucleotide inhibitors of } \\
\text { HIV reverse transcriptase (NNRTI) }\end{array}$ & & $\begin{array}{l}\text { Specialist advice, non- recommended co- } \\
\text { administration RILPIVIRINE, the increase } \\
\text { of which is not considered relevant, is an } \\
\text { exception }\end{array}$ \\
\hline CCR5 A ntagonists & & No dose adjustment necessary \\
\hline MAVAVIROC & Increased concentration (CYP3A inhibition) & Specialist advice for dose adjustment \\
\hline $\mathrm{Al} / \mathrm{M}$ or calcium carbonate- based antacids & & No dose adjustment \\
\hline \multicolumn{3}{|l|}{ Alpha antagonists } \\
\hline ALFUZOSIN & Increased concentration (CYP3A inhibition) & Contraindicated (hypotension) \\
\hline \multicolumn{3}{|l|}{ Anaesthetic } \\
\hline AL FENTANYL & Increased concentration (inhibition of CYP3A4) & $\begin{array}{l}\text { Dose reduction and monitoring (respiratory } \\
\text { depression risk) }\end{array}$ \\
\hline \multicolumn{3}{|l|}{ Antianginal/tymic antiaries } \\
\hline $\begin{array}{l}\text { AMIODARONE, DRONEDARONE } \\
\text { CHINIDINA, BEPRIDILE, IVRABRADINA, } \\
\text { RANOLAZINA }\end{array}$ & $\begin{array}{l}\text { Increased concentration (inhibition of CYP3A } \\
\text { and/or CYP2D6) }\end{array}$ & contraindicated \\
\hline $\begin{array}{l}\text { DYSOPYRAMID, FLECAINIDE, SYSTEMIC } \\
\text { LIDOCAINE, MEXILETINE, PROPAPHENONE }\end{array}$ & $\begin{array}{l}\text { Increased concentration (inhibition of CYP3A } \\
\text { and/or CYP2D6) }\end{array}$ & Caution and monitoring \\
\hline digoxin & $\begin{array}{l}\text { Increased concentration (P- glycoprotein } \\
\text { inhibition) }\end{array}$ & $\begin{array}{l}\text { Dose titration and accurate monitoring of } \\
\text { drug concentration }\end{array}$ \\
\hline \multicolumn{3}{|l|}{ Antibiotics } \\
\hline Clarithromycin & Increased AUC (CYP3A inhibition) & $\begin{array}{l}\text { Caution dose adjustment in patients with } \\
\text { renal impairment } \mathrm{CrCL}<30 \mathrm{ml} / \mathrm{min}\end{array}$ \\
\hline \multicolumn{3}{|l|}{ Anticoagulants } \\
\hline WARFARIN & $\begin{array}{l}\text { Theoretical mechanism of alteration of plasma } \\
\text { concentrations }\end{array}$ & INR monitoring \\
\hline APIXABAN, EDOXABAN, RIVAROXABAN & $\begin{array}{l}\text { Increased plasma concentrations (inhibition } \\
\text { of CYP3A \& P-gp) }\end{array}$ & contraindicated \\
\hline DAPIGATRAN; ticagrelor & $\begin{array}{l}\text { Increased plasma concentrations (inhibition } \\
\text { of CYP3A \& P-gp) }\end{array}$ & contraindicated \\
\hline \multicolumn{3}{|l|}{ Anticonvulsants } \\
\hline clonazepam & Increased concentration (CYP3A inhibition) & Clinical monitoring \\
\hline $\begin{array}{l}\text { CARBAMAZEPINA, FENOBARBITALE, } \\
\text { FENITOINA }\end{array}$ & $\begin{array}{l}\text { Reduced concentrations of darunavir and/or } \\
\text { cobicistat (CYP3A induction). }\end{array}$ & Contraindicated \\
\hline
\end{tabular}




\begin{tabular}{|c|c|c|}
\hline Co-administered Drug & Interaction mechanism & Clinical Recommendations \\
\hline \multicolumn{3}{|l|}{ Antidepressants and anxiolytics } \\
\hline ST. JOHN'S GRASS & $\begin{array}{l}\text { Reduction of darunavir and / or cobicistat } \\
\text { concentrations (CYP3A induction). }\end{array}$ & contraindicated \\
\hline $\begin{array}{l}\text { PAROXETINE, SERTR ALINA, AMITRIPTILINA, } \\
\text { DESIPRAMINA, IMIPRAMINA, } \\
\text { NORTRIPTILINA, TRAZODONE }\end{array}$ & $\begin{array}{l}\text { Increased plasma concentrations (CYP2D6 } \\
\text { and/or inhibition CYP3A) }\end{array}$ & Dosage reduction and clinical monitoring \\
\hline \multicolumn{3}{|l|}{ Antidiabetic } \\
\hline METFORMIN & Increased plasma concentration & Dosage reduction and clinical monitoring \\
\hline \multicolumn{3}{|l|}{ Antiemetics } \\
\hline DOMPERIDONE & Not studied & contraindicated \\
\hline \multicolumn{3}{|l|}{ Anti-fungals } \\
\hline $\begin{array}{l}\text { CLOTRIMAZOLO, FLUCONAZOLO, } \\
\text { ITRACONAZOLO, ISAVUCONAZOLO, } \\
\text { POSACONAZOLO }\end{array}$ & $\begin{array}{l}\text { Increased concentration } \\
\text { (inhibition of CYP3A \&/or P- gp) }\end{array}$ & $\begin{array}{l}\text { Caution, clinical monitoring and dosing } \\
\text { Voriconazole contraindicated }\end{array}$ \\
\hline \multicolumn{3}{|l|}{ Anti-gout } \\
\hline colchicine & $\begin{array}{l}\text { Increased concentration } \\
\text { (inhibition of P- gp and/or CYP3A4) }\end{array}$ & $\begin{array}{l}\text { Dosage reduction, contraindicated in the } \\
\text { presence of hepatic or renal impairment }\end{array}$ \\
\hline $\mathrm{H} 2$ receptor antagonists & & No dose adjustment necessary \\
\hline Antimycobacterials & & Specialized evaluation, tendentially contraindicated \\
\hline \multicolumn{3}{|l|}{ Anti-psychotics / neuroleptics } \\
\hline $\begin{array}{l}\text { PERFENAZINA, RISPERIDONE, } \\
\text { TIORIDAZINA }\end{array}$ & $\begin{array}{l}\text { Increased plasma concentrations } \\
\text { (inhibition of CYP3A, CYP2D6 and/or P-gp) }\end{array}$ & Dose reduction and clinical monitoring \\
\hline $\begin{array}{l}\text { LURASIDONE, PIMOZIDE, SERTINDOLO, } \\
\text { QUETIAPINA }\end{array}$ & & Contraindicated \\
\hline Anti-cancer & $\begin{array}{l}\text { Theoretical mechanism of concentration increase } \\
\text { (CYP3A inhibition) }\end{array}$ & Specialist evaluation, extreme caution \\
\hline \multicolumn{3}{|l|}{ Beta2 agonists } \\
\hline SALMETEROL & Increased concentration (CYP3A inhibition) & $\begin{array}{l}\text { Contraindicated (serious cardiovascular } \\
\text { adverse events, arrhythmias) }\end{array}$ \\
\hline \multicolumn{3}{|l|}{ Beta blockers } \\
\hline CARVEDILOL, METOPROLOL, TIMOLOL & $\begin{array}{l}\text { Plasma concentrations increased } \\
\text { (CYP3A inhibition) }\end{array}$ & Dose reduction and clinical monitoring \\
\hline \multicolumn{3}{|l|}{ Calcium antagonists } \\
\hline $\begin{array}{l}\text { AMLODIPINA, DILTIAZEM, } \\
\text { FELODIPINA, NIFEDIPINA, } \\
\text { NICARDIPINA, VERAPAMIL }\end{array}$ & $\begin{array}{l}\text { Increased concentration (inhibition of CYP3A } \\
\text { and / or CYP2D6) }\end{array}$ & Dose reduction and clinical monitoring \\
\hline
\end{tabular}




\begin{tabular}{|c|c|c|}
\hline Co-administered Drug & Interaction mechanism & Clinical Recommendations \\
\hline \multicolumn{3}{|l|}{ Corticosteroids } \\
\hline dexamethasone & $\begin{array}{l}\text { Reduction of Darunavir and / or cobicistat } \\
\text { concentrations (CYP3A induction) }\end{array}$ & Caution \\
\hline Proton pump inhibitors & & No dose adjustment \\
\hline \multicolumn{3}{|l|}{ Inhibitors of phosphodiesterase } \\
\hline TADALAFIL, SILDENAFIL & Increased concentration (CYP3A inhibition) & Contraindicated \\
\hline $\begin{array}{l}\text { Antivirals direct action against } \mathrm{HCV} \\
\text { (inhibitors NS3-4A protease) }\end{array}$ & $\begin{array}{l}\text { Increased plasma concentrations (combination } \\
\text { of mechanisms) }\end{array}$ & Contraindicated \\
\hline Endothelial receptor antagonists (Bosentan) & Increased concentration (theoretical consideration) & Contraindicated \\
\hline \multicolumn{3}{|l|}{ Immunosuppressant } \\
\hline CYCLOSPORINE & Increased concentration (CYP3A inhibition) & Monitoring of drug levels \\
\hline everolimus & & contraindicated \\
\hline \multicolumn{3}{|l|}{ Narcotics, Opioids } \\
\hline METHADONE & Increased concentration (theoretical consideration) & Monitoring of drug levels \\
\hline Buprenorphine / naloxone & Increased concentration (theoretical consideration) & Clinical monitoring \\
\hline FENTANYL, OXYCODONE, TRAMADOL & Increased concentration (theoretical consideration) & Clinical monitoring \\
\hline \multicolumn{3}{|l|}{ Opioid antagonists } \\
\hline NALOXEGOL & Not studied & contraindicated \\
\hline \multicolumn{3}{|l|}{ Sedatives / hypnotics } \\
\hline $\begin{array}{l}\text { BUSPIRONE, CLORAZEPAM, } \\
\text { DIAZEPAM, ESTAZOLAM, } \\
\text { FLURAZEPAM, ZOLPIDEM }\end{array}$ & Increased concentration (CYP3A inhibition) & Caution, dose reduction and clinical monitoring \\
\hline MIDAZOLAM (PARENTERAL) & & Only in intensive care. \\
\hline MIDAZOLAM (ORAL) & & contraindicated \\
\hline \multicolumn{3}{|l|}{ Urological drugs } \\
\hline FESOTERODINA, SOLIFENACINA & Not studied & Caution, dose reduction and clinical monitoring \\
\hline DAPOXETINE & Not studied & Contraindicated \\
\hline \multicolumn{3}{|l|}{ Contraceptives } \\
\hline & Alteration of plasma concentrations & Use additional methods of contraception \\
\hline drospirenone & & Monitoring for possible hypokalaemia \\
\hline $\begin{array}{l}\text { Statins and other hypo-lipidemic agents } \\
\text { (Lomitapide) }\end{array}$ & & Contraindicated \\
\hline
\end{tabular}


TABLE 4. Serious adverse effects

\begin{tabular}{|c|c|c|c|c|c|}
\hline & $\begin{array}{l}\text { Lopinavir / } \\
\text { Ritonavir }\end{array}$ & $\begin{array}{l}\text { Darunavir / } \\
\text { cobicistat }\end{array}$ & Chloroquine & $\begin{array}{l}\text { Hydroxychlor } \\
\text { oquine }\end{array}$ & Tolicizumab \\
\hline $\begin{array}{l}\text { Serious } \\
\text { adverse } \\
\text { effects }\end{array}$ & $\begin{array}{l}\text { Hypersensitivity } \\
\text { reaction, } \\
\text { angioedema } \\
\text { Stevens-Johnson } \\
\text { syndrome / } \\
\text { Toxic epidermal } \\
\text { necrolysis } \\
\text { / Erythema } \\
\text { multiforme } \\
\text { QT prolongation } \\
\text { \& } \\
\text { Torsade de Pointes } \\
\text { AV block, PR } \\
\text { prolongation } \\
\text { Hyperglycaemia, } \\
\text { hypertriglyceride } \\
\text { mia } \\
\text { Renal failure } \\
\text { Anemia, } \\
\text { leukopenia, } \\
\text { neutropenia } \\
\text { Pancreatitis } \\
\text { Hepatotoxicity }\end{array}$ & $\begin{array}{l}\text { Hepatotoxicity } \\
\text { Anorexia, } \\
\text { hyper- cholesterol- } \\
\text { aemia } \\
\text { hyper- triglyceridemia } \\
\text { Renal failure } \\
\text { Stevens- Johnson } \\
\text { syndrome rarely }\end{array}$ & $\begin{array}{l}\text { QT } \\
\text { prolongation \& } \\
\text { Torsades de Pointes } \\
\text { Reduction in seizure } \\
\text { threshold } \\
\text { Anaphylaxis or } \\
\text { anaphylactoid reaction } \\
\begin{array}{l}\text { Neuromuscula r } \\
\text { impairment }\end{array} \\
\begin{array}{l}\text { Neuropsychiat ric } \\
\text { disorders (potential to } \\
\text { increase } \\
\text { delirium) }\end{array} \\
\begin{array}{l}\text { Pancytopenia, } \\
\text { neutropenia, } \\
\text { thrombocytop enia, } \\
\text { aplastic anemia }\end{array} \\
\text { Hepatitis }\end{array}$ & $\begin{array}{l}\text { Hypoglycemia } \\
\text { QT prolongation } \\
\text { Cardio- myopathy } \\
\text { Muscle asthenia } \\
\text { Retinal or visual field } \\
\text { alterations } \\
\text { Skin reactions }\end{array}$ & 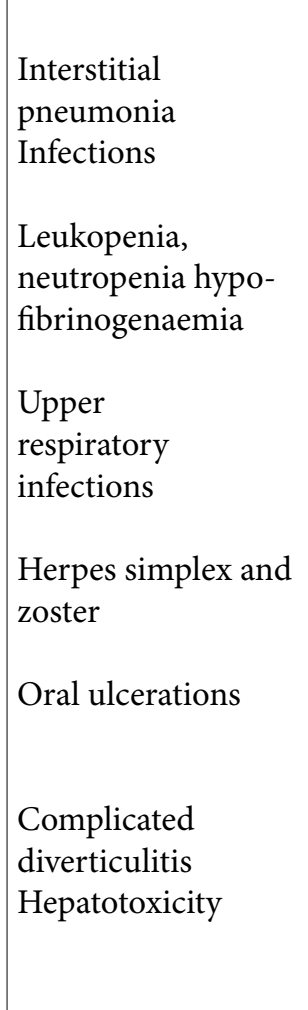 \\
\hline $\begin{array}{l}\text { Common } \\
\text { adverse } \\
\text { reactions }\end{array}$ & $\begin{array}{l}\text { Nausea / vomiting, } \\
\text { diarrhoea } \\
\text { Insomnia, anxiety }\end{array}$ & $\begin{array}{l}\text { Nausea / vomiting, } \\
\text { diarrhoea Insomnia, } \\
\text { anxiety Headache } \\
\text { Rash Muscle Pain }\end{array}$ & $\begin{array}{l}\text { Nausea / vomiting, } \\
\text { diarrhoea, abdominal } \\
\text { pain } \\
\text { Visual disturbance, } \\
\text { headache } \\
\text { Extrapyramida l } \\
\text { symptoms }\end{array}$ & $\begin{array}{l}\text { Nausea / vomiting, } \\
\text { diarrhoea, } \\
\text { abdominal pain } \\
\text { Visual disturbance, } \\
\text { headache } \\
\text { Skin rash, itching } \\
\text { Extra-pyramidal } \\
\text { symptoms }\end{array}$ & $\begin{array}{l}\text { Hypertension } \\
\text { Headache } \\
\text { Skin reactions } \\
\text { Conjunctivitis } \\
\text { Hyper- } \\
\text { cholesterolemia } \\
\text { Abdominal pain, } \\
\text { gastritis } \\
\text { Cough, dyspnoea }\end{array}$ \\
\hline $\begin{array}{l}\text { Contra- } \\
\text { indicated } \\
\text { in: }\end{array}$ & $\begin{array}{l}\text { Cardiac disease } \\
\text { ischemic } \\
\text { heart disease, } \\
\text { cardiomyopathy, } \\
\text { structural heart } \\
\text { disease, } \\
\text { QT prolongation } \\
\text { Liver disease }\end{array}$ & $\begin{array}{l}\text { Liver failure (class C } \\
\text { Child- Pugh) } \\
\text { Haemophilia }\end{array}$ & $\begin{array}{l}\text { Porphyria G6PD } \\
\text { deficiency Epilepsy } \\
\text { Heart failure Recent } \\
\text { myocardial } \\
\text { infarction }\end{array}$ & $\begin{array}{l}\text { Porphyria } \\
\text { Retinopathy } \\
\text { Maculopathies } \\
\text { Children } \\
<6 a<31 \mathrm{Kg}\end{array}$ & $\begin{array}{l}\text { Administration of } \\
\text { alive or attenuated } \\
\text { vaccines }\end{array}$ \\
\hline Monitor & Transaminases & Kidney function & $\begin{array}{l}\text { Serial complete blood } \\
\text { count QT interval }\end{array}$ & $\begin{array}{l}\text { Blood count, } \\
\text { glycemia, QT interval }\end{array}$ & $\begin{array}{l}\text { Cholesterol, } \\
\text { blood count, } \\
\text { transaminases }\end{array}$ \\
\hline
\end{tabular}

